\title{
WIARA FUNDAMENTEM FORMACJI SEMINARYJNEJ (2013)
}

Ekscelencje, Magnificencje, Szanowni Profesorowie, Wielebni Księża, Czcigodne Siostry Zakonne, Drodzy Alumni Archidiecezjalnego Wyższego Seminarium Duchownego w Białymstoku, Panie i Panowie!

Przeżywany obecnie Rok Wiary jest czasem pytania o sens życia i relacji do Boga. W Kościele to rok bardzo ciekawy. Przypominamy sobie naukę Soboru Watykańskiego II, odświeżamy prawdy katechizmowe, rozważamy Słowo Boże skierowane do każdego z nas. Nowa Ewangelizacja zadomowiła się na dobre w naszym słowniku teologicznym jako głoszenie kerygmatu dla odnowienia i pogłębienia wiary. Wszyscy bowiem, zwłaszcza dzisiaj, potrzebujemy zrozumienia istoty wiary, doświadczenia jej i konfrontowania z bieżącymi zagadnieniami życia codziennego. Ważnym wydarzeniem w Roku Wiary stał się wybór papieża Franciszka, który przychodzi do nas jako ten, który poprzez swoje wypowiedzi, gesty, prosty styl życia mówi o Ewangelii, w odmienny, bardziej przystępny sposób.

Podczas Mszy św. dla seminarzystów z okazji ich pielgrzymki w Roku Wiary do Rzymu powiedział:

Ewangelia mówi, że siedemdziesięciu dwóch powróciło z misji pełnych radości, gdyż doświadczyli mocy Imienia Chrystusa przeciw złu. Jezus to potwierdza: uczniom tym daje On siłę do pokonywania złego. Ale dodaje: Jednak nie z tego się cieszcie, że duchy się wam poddają, lecz cieszcie się, że wasze imiona zapisane są w niebie" (Łk 10, 20). Drodzy przyjaciele! Nie lękajcie się być radosnymi! Nie lękajcie się radości! Tej radości, którą daje nam Pan, gdy pozwalamy Mu wejść w nasze życie.... Nie bójcie się radości. Radości i odwagi!.

W Seminarium chcemy podjąć odpowiedzialnie to wyzwanie papieża Franciszka. Jako moderatorzy, wykładowcy, seminarzyści chcemy iść naprzód z radością i odwagą głosząc Ewangelię.

Aby stawało się to możliwe jesteśmy zaproszeni do podejmowania odpowiedzialności jedni za drugich poprzez kształtowanie w sobie poczucia podmiotowości, budowania autentycznych relacji międzyludzkich i personalnych, pełnych szacunku odniesień do siebie nawzajem. To jest punkt wyjścia, aby dojść do celu, do osobowego zjednoczenia z Bogiem. Seminarium to miejsce spotkania, to miejsce, gdzie krzyżują się drogi ludzi. W tej perspektywie Seminarium jawi się jako instytucja sprzyjająca temu, aby w kandydacie do kapłaństwa pogłębić wiarę, wydobyć z młodego człowieka takie nieodzowne walory jak wolność, autonomiczność w podejmowaniu decyzji, równość w relacjach, poznawanie prawdy o sobie i pokorne odniesienie się 
do Boga. Każdy młody człowiek poszukujący, oczekujący czegoś od życia to osoba rozwijająca się, poznająca, przeżywająca i działająca z szacunkiem i właściwą sobie wrażliwością. Trzeba zatem poznać samych siebie, mieć świadomość swoich możliwości, zdolności i ograniczeń, aby z pokorą kształtować relacje do siebie nawzajem i do Boga. Z tego wszystkiego rodzi się prawdziwa radość chrześcijańska, która nie jest krucha, krótkotrwała i przemijająca, ale taka, która daje nam odwagę.

Droga Wspólnoto Seminaryjna, Profesorowie i Alumni! Nowy rok akademicki to czas nowych zadań, wyzwań, ale i czas nowych szans i nadziei. Nowy rok w Seminarium to kolejny rok wspólnego odpowiadania z wiarą na Boży dar powołania do kapłaństwa. Otwierając kolejny rok akademicki w AWSD za papieżem Franciszkiem życzę radości i odwagi wszystkim tworzącym seminaryjną wspólnotę. Quod bonum, felix, faustum, fortunatumque sit! Rok akademicki 2013/2014 w Archidiecezjalnym Wyższym Seminarium Duchownym w Białymstoku ogłaszam za otwarty!

ks. dr hab. Andrzej Proniewski, prof. UwB 